\title{
Auditors offering both corporate social responsibility (CSR) assurance and financial auditing could be best option for firms
}

\section{Lorenzo Dal Maso}

Gerald J. Lobo

Francesco Mazzi

Luc Paugam

\section{Video Byte}

Keywords: carbon footprint, ethical principles, regulations, audit firms, corporate social responsibility, CSR, CSR Assurance, CSR risks, financial audits, restatement, going concern risk, going concern opinion, knowledge spillover, non-audit services, stakeholder, audit report, earnings, joint provision, ESSEC Business School

Posted Date: October 24th, 2019

DOI: https://doi.org/10.21203/rs.2.16598/v1

License: @ (i) This work is licensed under a Creative Commons Attribution 4.0 International License. Read Full License 


\section{Abstract}

Worldwide, today's stakeholders are concerned with more than shareholder value They care about a firm's carbon footprint the production of safe and healthy products and suppliers that respect regulations and ethical principles For that reason, firms started issuing corporate social responsibility (CSR) reports, and audit firms now provide CSR assurance services That begs the question: Should firms use the same audit firm to perform both CSR assurance and financial audits? Or seek a different CSR assurance provider altogether? Researchers recently weighed in by analyzing more than 28,000 firm-year observations from 55 countries They discovered that audit firms offering CSR assurance + financial audits obtain more information about CSR risks than firms providing financial audits only Joint-service audit firms deliver better audit quality and make fewer Type II going concern errors have clients that book larger environmental and litigation provisions are less likely to provide income-decreasing restatements and don't charge significantly higher audit or total fees These findings could prove useful to countless firms as the exposure to CSR risks continues to accelerate 